\title{
Opodatkowanie podatkiem dochodowym od osób prawnych rozporządzania rzeczą przechowywaną w depozycie nieprawidłowym
}

The taxation of the Corporate Income Tax of disposal of goods from deposit incorrect

Streszczenie. Artykuł przedstawia opodatkowanie podatkiem dochodowym od osób prawnych rozporządzania rzeczą przechowywaną w depozycie nieprawidłowym. Autor wskazuje moment ustalenia przychodu z czynności rozporządzania, który winien być odroczony do czasu zakończenia możliwości rozporządzania rzeczą przechowywaną w depozycie nieprawidłowym, kiedy zostaną ustalone koszty uzyskania tego przychodu. Dopiero w tym momencie możliwe będzie ustalenie dochodu.

Słowa kluczowe: podatek dochodowy od osób prawnych; depozyt nieprawidłowy; rozporządzanie.

Abstract. The article presents the taxation of the Corporate Income Tax of disposal of goods from deposit incorrect. The author indicates the moment of recog- 
nition of revenue from the operations of disposal of goods, which should be deferred until the completion of the possibilities of disposal of goods from deposit incorrect, when they are fixed costs of that income. Only at this point it will be possible to determine income.

Keywords: Corporate Income Tax; deposit incorrect; disposal.

\section{Wprowadzenie}

Instytucja prawna, jaką jest depozyt nieprawidłowy, ma swoje konsekwencje cywilnoprawne oraz prawnopodatkowe ${ }^{1}$. Poniższe rozważania dotyczą konsekwencji podatkowych występujących na gruncie podatku dochodowego od osób prawnych, który regulowany jest przez ustawę z dnia 15 lutego 1992 r. o podatku dochodowym od osób prawnych $^{2}$, w szczególności analizie prawnopodatkowej poddana zostanie czynność rozporządzania przez depozytariusza rzeczą przekazaną mu w przechowanie do depozytu nieprawidłowego.

Konstrukcja cywilnoprawna stosunku prawnego depozytu nieprawidłowego oraz brak precyzyjnego wskazania $\mathrm{w}$ ustawie podatkowej momentu wykazania przychodu, kosztu jego uzyskania, a tym samym dochodu z rozporządzania rzeczą z depozytu nieprawidłowego powodują, że podmioty stosujące prawo podatkowe mogą mieć trudność w określeniu elementów istotnych dla konstrukcji podatku dochodowego od osób prawnych przy określaniu konsekwencji podatkowych czynności rozporządzania rzeczą z tego depozytu.

Celem niniejszych rozważań jest, po pierwsze, wskazanie, że w akcie normatywnym regulującym podatek dochodowy od osób prawnych, ze względu na cywilnoprawną konstrukcję depozytu nieprawidłowego, brak precyzyjnego określenia momentu, kiedy podatnik tego podatku powinien ustalić przychód, koszt jego uzyskania, a tym samym dochód uzyskany $\mathrm{z}$ transakcji rozporządzania rzeczą przechowywaną $\mathrm{w}$ depozycie

\footnotetext{
1 R. Golat, Umowa depozytu nieprawidłowego - implikacje w podatku dochodowym, Komentarz praktyczny ABC, LEX nr 469833737.

2 Tekst jedn. Dz.U. z 2016 r., poz. 380, dalej: PdopU.
} 
nieprawidłowym. Po drugie, w oparciu o konstrukcję dochodu, przychodu oraz kosztu jego uzyskania, należy wskazać, że sposób opodatkowania winien być oparty o koncepcję odroczonego rozpoznania, dla celów podatkowych, przychodu $\mathrm{z}$ transakcji rozporządzania przedmiotem z depozytu nieprawidłowego. Koncepcja ta polega na tym, że podatnik powinien rozpoznać przychód z czynności rozporządzania rzeczą przechowywaną w depozycie nieprawidłowym dopiero w momencie wydania rzeczy stronie depozytu nieprawidłowego, którego wartość tożsama jest wynagrodzeniem - ceną - jaką uzyskał depozytariusz z transakcji zbycia przedmiotu depozytu osobie trzeciej. Natomiast kosztem uzyskania tego przychodu jest wartość rzeczy takiej samej ilości, tego samego gatunku i jakości w takiej samej formie, jaka została złożona do depozytu nieprawidłowego, którą przechowawca nabył w celu zwrotu tej rzeczy stronie umowy depozytu nieprawidłowego.

\section{Instytucja prawna depozytu nieprawidłowego}

Depozyt nieprawidłowy (z łac. depositum irregulare) jest instytucją prawną wywodzącą się z prawa cywilnego. Jej regulacja prawna znajduję się w przepisie art. 845 ustawy z dnia 23 kwietnia 1964 roku Kodeks Cywilny ${ }^{3}$, zgodnie z którym „jeżeli z przepisów szczególnych albo z umowy lub okoliczności wynika, że przechowawca może rozporządzać oddanymi na przechowanie pieniędzmi lub innymi rzeczami oznaczonymi tylko co do gatunku, stosuje się odpowiednio przepisy o pożyczce (depozyt nieprawidłowy). Czas i miejsce zwrotu określają przepisy o przechowaniu.”

Przedmiotem depozytu nieprawidłowego określanego również jako umowa o przechowanie nieprawidłowe ${ }^{4}$, mogą być zarówno oddane w przechowanie pieniądze, jak również inne rzeczy oznaczone tylko co do gatunku. Cel gospodarczy przechowania nieprawidłowego polega na zaspokojeniu interesu obu stron umowy, bowiem składający rzecz na

Tekst jedn. Dz.U. z 2016 r. poz. 380 ze zm., dalej: KC.

Zob. W. Czachórski, Zobowiq̨zania. Zarys wykładu, Warszawa 2009, s. 517. 
przechowanie nie ponosi ryzyka ich utraty czy też uszkodzenia, a depozytariusz (przechowawca) uzyskuje prawo do rozporządzania złożonymi w depozycie rzeczami według własnej woli ${ }^{5}$. Czynnością cywilnoprawną polegającą na rozporządzaniu przez depozytariusza rzeczą złożoną na przechowanie do depozytu nieprawidłowego może być sprzedaż przechowywanej rzeczy osobie trzeciej.

Stosunek prawny, który powstaje na podstawie umowy przechowania nieprawidłowego, łączy w sobie jednocześnie element przechowania oraz pożyczki. Ustawodawca wprost wskazał, w przepisie art. $845 \mathrm{KC}$, że do depozytu nieprawidłowego stosuje się przepisy o pożyczce z wyłączeniem kwestii czasu i miejsca zwrotu rzeczy znajdujących się w depozycie nieprawidłowym, które określają przepisy o przechowaniu, w szczególności przepis art. 844 KC. Zgodnie $\mathrm{z}$ tym składający rzecz na przechowanie w depozycie nieprawidłowym w każdym czasie trwania tego stosunku prawnego może żądać zwrotu przedmiotu depozytu i to bez względu na kwestię terminu obowiązywania umowy depozytu nieprawidłowego.

Przechowanie przedmiotu w depozycie nieprawidłowym należy rozumieć jako zaewidencjonowanie przedmiotu depozytu nieprawidłowego oraz dbanie, by był możliwy zwrot tego przedmiotu (tego samego gatunku i tej samej jakości) stronie umowy ${ }^{6}$.

Jak zostało powyżej wskazane, do depozytu nieprawidłowego mają zastosowanie również przepisy dotyczące pożyczki. Fundamentalnym zagadnieniem związanym ze stosowaniem przepisów dotyczących pożyczki do umowy depozytu nieprawidłowego jest to, że własność rzeczy znajdujących się w depozycie przechodzi na depozytariusza. Z tym związana jest możliwość rozporządzania przedmiotem depozytu nieprawidłowego według zamysłu depozytariusza. Inną istotną kwestią jest ciążący na przechowawcy obowiązek zwrotu takiej samej ilości pieniędzy czy rzeczy tego samego gatunku i tej samej jakości. Ważne jest,

\footnotetext{
5 K. Kopaczyńska-Pieczniak, Komentarz do art. 845 Kodeksu Cywilnego, [w:] A. Kidyba (red.), Kodeks cywilny. Komentarz. Tom III. Zobowiqzania - część szczególna wyd. II, LEX nr 46294.

6 Tamże.
} 
że depozytariusz nie ma obowiązku zwrotu tych samych pieniędzy albo innych rzeczy oznaczonych co do gatunku ${ }^{7}$.

Należy również wskazać, że depozytariusz może pobierać wynagrodzenie za przechowywanie przedmiotu depozytu. Jednak możliwy jest również nieodpłatny charakter tego stosunku prawnego. Jednak na potrzeby niniejszego opracowania kwestia ta nie ma znaczenia.

\section{Rozporządzanie przedmiotem złożonym w depozycie nieprawidłowym a konsekwencje podatkowe w po- datku dochodowym od osób prawnych}

\subsection{Konsekwencje podatkowe w podatku dochodowym od osób prawnych depozytu nieprawidłowego}

Stosunek prawny depozytu nieprawidłowego nie rodzi skutków podatkowych w podatku dochodowym od osób prawnych ${ }^{8}$, co oznacza, że depozyt nieprawidłowy nie generuje powstania przychodu ani kosztów jego uzyskania. W interpretacji indywidualnej z dnia 18 grudnia 2014 r. Dyrektor Izby Skarbowej w Poznaniu ${ }^{9}$ stwierdził, że: „(...) przyjęcie od klienta towaru w depozyt nieprawidłowy, podobnie jak to ma miejsce w przypadku pożyczki, jest zdarzeniem podatkowo neutralnym, w tym sensie, że z jednej strony otrzymany przez Spółkę towar nie stanowi przychodu podatkowego, z drugiej zaś strony zwrot tego towaru nie może być uznany za koszt uzyskania przychodów”. Wojewódzki Sąd Administracyjny we Wrocławiu w wyroku z dnia 8 lipca 2015 r. ${ }^{10}$ stwierdził, że: „Jako że otrzymanie środków pieniężnych lub rzeczy oznaczonych co do gatunku w ramach umów depozytu nieprawidłowego nie powoduje rozpoznania przychodów lub

\footnotetext{
Tamże.

Dlatego też można stwierdzić, że depozyt nieprawidłowy jest „neutralny podatkowo”. Interpretacja indywidualna Ministra Finansów z dnia 18 grudnia 2014 r. nr ILPB3/423474/14-6/EK, LEX nr 184812120.

10 Wyrok Wojewódzkiego Sądu Administracyjnego we Wrocławiu z dnia 8 lipca 2015 r., I SA/Wr 906/15, LEX nr 521877969.
} 
kosztów podatkowych, to również zwrot pieniędzy lub rzeczy oznaczonych co do gatunku nie będzie rodził skutków podatkowych, tzn. nie powstanie ani przychód, ani koszt uzyskania przychodów.”

Zgodnie z koncepcją depozytu nieprawidłowego depozytariusz przedmiotu złożonego w depozycie nieprawidłowym ma prawo nim rozporządzać wedle własnego uznania. Wskazana cywilistyczna koncepcja ma swoje konsekwencje na gruncie analizowanego podatku dochodowego od osób prawnych.

W przypadku, gdy depozytariusz jest podatnikiem podatku dochodowego od osób prawnych ${ }^{11}$, konsekwencje podatkowe rozporządzania przedmiotem złożonym do depozytu nieprawidłowego należy rozpatrywać na kanwie ustawy z dnia 15 lutego 1992 r. o podatku dochodowym od osób prawnych.

Analizując sposób opodatkowania podatkiem dochodowym od osób prawnych transakcji rozporządzania rzeczą przechowywaną w depozycie nieprawidłowym, należy ustalić kwestię przychodu, kosztów jego uzyskania i finalnie uzyskanego dochodu z tej transakcji.

\subsection{Określenie przychodu, kosztu jego uzyskania oraz dochodu z rozporządzania rzeczą przechowywaną w depozycie nieprawidłowym}

\subsubsection{Dochód z rozporządzania rzeczą przechowywaną w depozycie nieprawidłowym}

Rozporządzanie przechowywaną rzeczą w depozycie nieprawidłowym polega na tym, że podatnik zbywa tę rzecz - uzyskuje przychód - a na-

11 Czyli jest osobą prawną lub spółką kapitałową w organizacji czy też jednostką organizacyjną niemającą osobowości prawnej, spółką komandytowo-akcyjną mającą siedzibę lub zarząd na terytorium Rzeczypospolitej Polskiej albo spółką niemającą osobowości prawnej mającą siedzibę lub zarząd w innym państwie, jeżeli zgodnie z przepisami prawa podatkowego tego innego państwa jest traktowana jak osoba prawna i podlega w tym państwie opodatkowaniu od całości swoich dochodów bez względu na miejsce ich osiągania. 
stępnie nabywa tej samej ilości, tego samego gatunku i tej samej jakości rzecz w celu jej zwrotu stronie umowy depozytu nieprawidłowego - rozpoznaje koszt uzyskania tego przychodu.

Zgodnie $\mathrm{z}$ art. 7 ust. 1 PdopU przedmiotem opodatkowania podatkiem dochodowym jest dochód bez względu na rodzaj źródeł przychodów, z jakich dochód ten został osiągnięty; w wypadkach, o których mowa w art. 21 i 22 PdopU, przedmiotem opodatkowania jest przychód. Z kolei ust. 2 art. 7 PdopU określa definicję dochodu, którym jest osiągnięta w roku podatkowym nadwyżka sumy przychodów nad kosztami ich uzyskania $^{12}$. Istotne jest również, iż zgodnie z brzmieniem art. 7 ust. 1 i ust. 2 PdopU w przypadku wystąpienia u podatnika przychodu związanego z daną czynnością ma on prawo ustalić koszty uzyskania tego przychodu. W orzecznictwie wyrażone zostało jednolite stanowisko, zgodnie z którym najistotniejszą przesłanką przy ustalaniu elementów dochodu jest wystąpienie związku przyczynowo-skutkowego pomiędzy danym przychodem a kosztem $^{13}$. W wyroku Naczelnego Sądu Administracyjnego z dnia 14 stycznia 2010 r. $^{14}$ jednoznacznie wskazano, że „(...) podstawą opodatkowania podatkiem dochodowym jest dochód, a nie przychód (art. 7 ust. 1-2 oraz art. 18 ust. 1 PdopU), a przychody uzyskiwane są co do zasady na skutek ponoszenia określonych wydatków (art. 15 ust. 1 PdopU).”

Zgodnie z koncepcją rozporządzania rzeczą przechowywaną w depozycie nieprawidłowym dochodem jest definitywne przysporzenie majątkowe (wzbogacenie) depozytariusza. W związku z tym przysporzeniem majątkowym jest różnica uzyskanego przychodu z tej transakcji oraz kosztów jego uzyskania. Obie te składowe dochodu winny być rozpoznane przez podatnika (depozytariusza) w momencie nabycia rzeczy celem zwrotu stronie umowy depozytu nieprawidłowego, gdyż dopiero w tym momencie podatnik będzie de facto w stanie określić swój stopień przysporzenia majątkowego z analizowanej transakcji, które to będzie podlegać opodatkowaniu.

\footnotetext{
12 Jeżeli koszty uzyskania przychodów przekraczają sumę przychodów, to różnica jest stratą.

13 Por. np. wyrok NSA z dnia 1 października 2014 r., II FSK 2463/2012; wyrok NSA z dnia 4 lipca 2014 r., II FSK 1863/2012; wyrok NSA z dnia 21 sierpnia 2013 r., II FSK 2452/2011, CBOSA.

14 Wyrok NSA z dnia 14 stycznia 2010 r., II FSK 1286/08, CBOSA.
} 


\subsubsection{Przychód z rozporządzania rzeczą przechowywaną w depozycie nieprawidłowym}

Ustawodawca w art. 12 ust. 1 pkt 1 PdopU wskazał, że przychodami są w szczególności otrzymane pieniądze, wartości pieniężne, w tym również różnice kursowe. W ustępie 3 art. 12 PdopU wprost został uregulowany przychód związany z działalnością gospodarczą i z działami specjalnymi produkcji rolnej. Za przychody te, osiągnięte w roku podatkowym, uważa się również należne przychody, nawet gdyby nie zostały jeszcze faktycznie otrzymane, po wyłączeniu wartości zwróconych towarów, udzielonych bonifikat i skont. Za datę powstania przychodu, o którym mowa $\mathrm{w}$ art. 12 ust. 3 PdopU, uważa się, z zastrzeżeniem ust. 3c-3e, dzień wydania rzeczy, zbycia prawa majątkowego lub wykonania usługi albo częściowego wykonania usługi, nie później niż dzień albo wystawienia faktury albo uregulowania należności.

Dysonans dotyczący ujęcia przysporzenia majątkowego w związku $\mathrm{z}$ rozporządzeniem rzeczą $\mathrm{z}$ depozytu nieprawidłowego dotyczy, po pierwsze, momentu rozpoznania przychodu dla celów podatkowych oraz, po drugie, określenia wysokości przychodu. Problem ustalenia momentu, kiedy powstaje przychód z rozporządzania rzeczą przechowywaną w depozycie nieprawidłowym, wynika $\mathrm{z}$ istoty depozytu nieprawidłowego, bowiem ze swojej specyfiki rozporządzanie to jest podobne do tzw. krótkiej sprzedaży papierów wartościowych. Krótka sprzedaż polega na sprzedaży pożyczonych papierów wartościowych przy spadkach kursów i odkupu ich po niższej cenie ${ }^{15}$. Ustawodawca dla takiego rodzaju operacji dokonywanych w ramach „krótkiej sprzedaży” przewidział szczególny moment powstania przychodu, który znalazł swój wyraz w art. 12 ust. 4c PdopU. W przypadku zdeponowanych rzeczy w depozycie nieprawidłowym depozytariusz również dokonuje sprzedaży „pożyczonych” rzeczy, a następnie nabywa rzeczy takiej samej ilości oraz tego samego gatunku i jakości w takiej samej formie, jaką przyjął w depozyt po cenach niższych albo wyższych niż pierwotna wartość zdeponowanej rzeczy. W wyroku z dnia 3 czerwca 2015 r. Wojewódzki

15 Szerzej: W. Bień, Rynek papierów wartościowych, Warszawa 2008, s. 232. 
Sąd Administracyjny w Szczecnie ${ }^{16}$ stwierdził, że art. 12 ust. 4c PdopU „(...) dotyczy odpłatnego zbycia papierów pożyczonych wartościowych na zasadach określonych w odrębnych przepisach (sprzedaż krótka), wówczas przychód ustala się na dzień zwrotu pożyczonych papierów wartościowych lub na dzień, w którym miał nastąpić zwrot tych papierów wartościowych zgodnie z zawartą umową pożyczki. Przepis ten jednak jako przepis szczególny $\mathrm{w}$ zakresie regulacji momentu powstania przychodu nie powinien być stosowany do innych sytuacji aniżeli zostały w nim unormowane, czy do odpłatnego zbycia pożyczonych papierów wartościowych. Jednak towary oznaczone co do gatunku są zasadniczo odmienne od papierów wartościowych, gdyż nie inkorporują praw i nie podlegają obrotowi uregulowanemu w sposób szczególny.” Z wykładnią wskazaną przez Wojewódzki Sąd Administracyjny w Szczecinie należy się zgodzić, gdyż wolą ustawodawcy tylko przychód z odpłatnego zbycia papierów wartościowych na rynku regulowanym w ramach „krótkiej sprzedaży” jest unormowany przez art. 12 ust. 4c PdopU i nie może być stosowany do rozporządzania rzeczą przechowywaną w depozycie nieprawidłowym mimo podobieństw do rozporządzania papierami wartościowymi w ramach tzw. krótkiej sprzedaży.

Z istoty depozytu nieprawidłowego wynika, że depozytariusz ma prawo dokonywać czynności rozporządzania rzeczą przechowywaną. W związku z tym w momencie zbycia tej rzeczy na depozytariuszu ciąży zobowiązanie zwrotu tej rzeczy stronie umowy depozytu nieprawidłowego. W związku z tym czynność rozporządzania rzeczą przechowywaną $\mathrm{w}$ depozycie nieprawidłowym powinno się postrzegać jako całość tzn. zbycie rzeczy oraz nabycie jej celem zwrotu, a tym samym wygaśnięcia stosunku prawnego depozytu nieprawidłowego.

Tak postrzegana czynność rozporządzania jako transakcja zbycia, a następnie nabycia powoduje, że nie jest oczywiste, kiedy podatnik winien rozpoznać przychód $\mathrm{z}$ tego źródła. $\mathrm{Z}$ jednej strony momentem tym jest zbycie rzeczy, natomiast z drugiej strony momentem, w którym powinien zostać rozpoznany przychód jest moment zwrotu nabytej rzeczy osobie

16 Wyrok WSA w Szczecinie z dnia 3 czerwca 2015 r., I SA/Sz 424/15, CBOSA. 
będącej stroną stosunku prawnego depozytu nieprawidłowego. Rozbieżność co do momentu rozpoznania otrzymanego przysporzenia jako przychód powoduje zmianę momentu powstania obowiązku podatkowego.

Relewantne dla ustalenia momentu ujęcia przychodu z rozporządzania rzeczą z depozytu nieprawidłowego jest sama konstrukcja dochodu w podatku dochodowym od osób prawnych. Zgodnie z art. 7 ust.1 PdopU ustawodawca opodatkowuje dochód (w wyjątkowych sytuacjach przychód, jednak kwestia ta nie dotyczy analizowanego zagadnienia). Otrzymanie przez depozytariusza wynagrodzenia (cena) w związku ze zbyciem rzeczy przechowywanej w depozycie nieprawidłowym nie może być rozpoznane dla celów podatkowych jako przychód, gdyż w tym momencie podatnik nie jest $\mathrm{w}$ stanie wykazać jakiegokolwiek kosztu uzyskania tego przychodu. Koszt ten zostanie dopiero rozpoznany w momencie nabycia rzeczy celem zwrotu jej stronie depozytu nieprawidłowego.

W związku z tym należy poddać rozwadze, czym jest otrzymane przez depozytariusza wynagrodzenie $\mathrm{w}$ momencie zbycia rzeczy osobie trzeciej. Wynagrodzenie to, $\mathrm{w}$ momencie zbycia rzeczy, nie stanowi, w ujęciu prawa podatkowego, przychodu $\mathrm{z}$ rozporządzania rzeczą z depozytu nieprawidłowego. Natomiast wynagrodzenie to stanowi przychód z tej czynności w ujęciu prawa bilansowego. Podstawowym aktem normatywnym regulującym prawo bilansowe jest ustawa $\mathrm{z}$ dnia 29 września 1994 r. o rachunkowości ${ }^{17}$. W ustawie o rachunkowości prawodawca wskazał w art. 3 ust. 1 pkt 30, że pod pojęciem przychodów w ujęciu bilansowym (przychodów i zysków) rozumie się uprawdopodobnione powstanie $\mathrm{w}$ okresie sprawozdawczym korzyści ekonomicznych o wiarygodnie określonej wartości w formie zwiększenia wartości aktywów albo zmniejszenia wartości zobowiązań, które doprowadzą do wzrostu kapitału własnego lub zmniejszenia jego niedoboru w inny sposób niż wniesienie środków przez udziałowców lub właścicieli. Innymi słowy, w ujęciu bilansowym „przychodem jest wszystko, co łączy się ze zwiększeniem aktywów, zmniejszeniem

17 Tekst jedn. Dz.U. z 2016 r. poz. 1047, dalej: ustawa o rachunkowości. 
pasywów oraz inne przysporzenia majątkowe otrzymane jako darowizny lub po znacznie niższej wartości niż ich wartość rynkowa, z wyłączeniem enumeratywnie wymienionych zdarzeń.”18 W literaturze przedmiotu wskazuje się na odrębność pojęciową w zakresie określenia pojęcia przychodu $\mathrm{w}$ prawie podatkowym i w prawie bilansowym ${ }^{19}$. W związku z tym moment rozpoznania przychodu z czynności rozporządzania rzeczą z depozytu nieprawidłowego będzie odmienny dla celów prawa podatkowego i dla celów prawa bilansowego, bowiem data powstania przychodu dla celów prawa podatkowego winna zostać wskazana na moment zakończenia stosunku depozytu nieprawidłowego. Natomiast dla celów prawa bilansowego momentem powstania tego przychodu będzie chwila dokonania zbycia rzeczy przechowywanej w depozycie.

Dla ustalenia przychodu z rozporządzania rzeczą przechowywaną w depozycie nieprawidłowym istotną kwestią jest wartość tego przychodu. Ta winna być ustalona w oparciu o wynagrodzenie - cenę jakie otrzymał depozytariusz od osoby trzeciej, dokonując zbycia rzeczy przechowywanej w depozycie nieprawidłowym. Szczególnie jest to istotne, gdyż wartość rynkowa zbywanej rzeczy $\mathrm{z}$ depozytu nieprawidłowego może w czasie ulegać zmianie. Dlatego też uzyskany przez depozytariusza przychód z analizowanej transakcji winien być tożsamy z wartością, po jakiej zbył depozytariusz tę rzecz.

\subsubsection{Koszty uzyskania przychodu z rozporządzania rzeczą przechowywaną $w$ depozycie nieprawidłowym}

Koszty uzyskania przychodów, zgodnie z art. 15 ust. 1 PdopU, są to koszty poniesione $\mathrm{w}$ celu osiągnięcia przychodu lub zachowania albo zabezpieczenia źródła przychodów, z wyjątkiem kosztów wymienionych w art. 16 ust. 1 PdopU. Powyższe oznacza, że podatnik ma prawo do

18 J. Adamczuk, W. Szewc, K. Ziółkowska, Ujęcie przychodów według regulacji prawa bilansowego i podatkowego w Polsce, „Zeszyty Teoretyczne Rachunkowości” 2010, t. 54, s. 9-10.

19 P. Borszowski, Działalność gospodarcza w konstrukcji prawnej podatku, Warszawa 2010, s. 252. 
odliczenia dla celów podatkowych wszelkich wydatków, pod warunkiem, iż nie zostały one wymienione w art. 16 ust. 1 PdopU, oraz że wykaże ich związek z prowadzoną działalnością, a ich poczynienie ma lub może mieć wpływ na możliwość powstania przychodu (w tym zachowania lub zabezpieczania przychodu). W literaturze przedmiotu wskazuje się, że przepis ten konstytuuje zasadę, stosownie do której pomiędzy kosztem podatkowym oraz przychodami podatnika musi wystąpić związek przyczynowo-skutkowy ${ }^{20}$.

Jak zostało już wskazane, przechowanie przedmiotu w ramach depozytu nieprawidłowego, podobnie jak to ma miejsce w przypadku pożyczki, jest zdarzeniem podatkowo neutralnym, w tym sensie, że z jednej strony otrzymana przez depozytariusza rzecz nie stanowi przychodu podatkowego, z drugiej zaś strony zwrot tej rzeczy nie może być uznany za koszt uzyskania przychodów.

Dyrektor Izby Skarbowej w Poznaniu wskazał w interpretacji indywidualnej z dnia 18 grudnia 2014 r. $^{21}$, po pierwsze, że: „Koszt uzyskania przychodów nie powstanie również w momencie przyjęcia towaru od klienta na przechowanie i jednocześnie przyjęcie na magazyn sprzedaży. Jak słusznie zauważył Wnioskodawca kosztem uzyskania przychodów jest m.in. taki koszt, który został poniesiony przez podatnika, tj. w ostatecznym rozrachunku musi on zostać pokryty z zasobów majątkowych podatnika. W niniejszej sprawie taka sytuacja nie występuje. Przyjmując towar do depozytu Wnioskodawca nie ponosi wydatku, lecz - jak wskazuje we wniosku - jedynie wycenia towar oddany przez klienta do depozytu. Czynności tej jednak nie można utożsamiać z poniesieniem kosztu, o którym mowa w art. 15 ust. 1 ustawy o podatku dochodowym od osób prawnych”. Po drugie, Dyrektor Izby Skarbowej w Poznaniu stwierdził, że: „W świetle powyższego, wartość towaru oddanego do depozytu ustalona przez Spółkę według wartości rynkowej towaru z dnia przyjęcia na magazyn sprzedaży bądź z dnia

20 Szerzej: A. Gomułowicz, Prawna formuła kosztu podatkowego, Warszawa 2016, s. 34-49.

21 Interpretacja indywidualna Dyrektora Izby Skarbowej w Poznaniu z dnia 18 grudnia 2014 r. nr ILPB3/423-474/14-6/EK, LEX nr 184812120. 
sprzedaży towaru na rzecz osoby trzeciej nie stanowi dla Spółki kosztu uzyskania przychodu, o którym mowa w art. 15 ust. ustawy o podatku dochodowym od osób prawnych.” Powyższe wskazuje, że depozytariuszpodatnik nie może rozpoznać kosztu uzyskania przychodu:

1) w momencie przyjęcia rzeczy na przechowanie;

2) w momencie przyjęcia na magazyn sprzedaży rzeczy;

3) w momencie sprzedaży rzeczy na rzecz osoby trzeciej.

Koszty uzyskania przychodu $\mathrm{z}$ rozporządzania rzeczą przechowywaną $\mathrm{w}$ depozycie nieprawidłowym teoretycznie mogą wystąpić w następujących momentach: przyjęcia rzeczy z powrotem do depozytu nieprawidłowego, przyjęcia rzeczy na magazyn sprzedaży, czyli przygotowanie rzeczy do ponownej sprzedaży, w momencie sprzedaży rzeczy osobie trzeciej oraz w momencie wydania rzeczy stronie umowy depozytu nieprawidłowego. Zgodnie $\mathrm{z}$ powyższym stwierdzeniem Dyrektora Izby Skarbowej w Poznaniu ani w momencie przyjęcia rzeczy na przechowanie, ani $\mathrm{w}$ momencie przyjęcia rzeczy na magazyn sprzedaży oraz sprzedaży rzeczy na rzecz osoby trzeciej, depozytariuszpodatnik nie może szukać kosztów uzyskania przychodu z rozporządzania rzeczą przechowywaną w depozycie nieprawidłowym. W związku z tym jedynym momentem, w którym depozytariusz powinien rozpoznać koszty uzyskania przedmiotowego przychodu jest moment wydania rzeczy przechowywanej $\mathrm{w}$ depozycie nieprawidłowym stronie umowy tego stosunku prawnego.

Koszt ten należy utożsamiać z wartością rzeczy, jaką depozytariusz nabył w celu wydania jej stronie umowy depozytu nieprawidłowego. Innym problemem, który nie został poruszony, jest kwestia ujęcia jako kosztów uzyskania przychodu z rozporządzania rzeczą przechowywaną w depozycie nieprawidłowym wartości rzeczy, która została przeniesiona z innego depozytu, którym również zarządza ten sam depozytariusz.

Reasumując, z czynności rozporządzania rzeczą $\mathrm{z}$ depozytu nieprawidłowego depozytariusz uzyska przychód oraz będzie mógł wykazać koszt jego uzyskania. Dopiero w momencie zwrotu rzeczy stronie umowy depozytu nieprawidłowego depozytariusz będzie mógł wykazać koszty uzyskania przychodu, dlatego też w tym momencie 
depozytariusz winien rozpoznać przychód w wysokości wartości sprzedanej rzeczy $\mathrm{z}$ depozytu nieprawidłowego. Inne stosowanie przepisów prawa podatkowego powodowałoby naruszenie art. 7 ust. 1 i 2 PdopU, gdyż jak wskazał Naczelny Sąd Administracyjny w wyroku z dnia 14 stycznia 2010 r. $^{22}$, „(..) podstawą opodatkowania podatkiem dochodowym jest dochód, a nie przychód (art. 7 ust. 1-2 oraz art. 18 ust. 1 PdopU), a przychody uzyskiwane są co do zasady na skutek ponoszenia określonych wydatków (art. 15 ust. 1 PdopU)”.

\section{Wnioski}

Analiza opodatkowania rozporządzania rzeczą przechowywaną w depozycie nieprawidłowym skłania do wniosku, że największy problem stanowi ustalenie momentu powstania przychodu w ujęci prawa podatkowego oraz powstania kosztu jego uzyskania. Ustawodawca wprost w PdopU nie wskazuje, jak w przypadku przychodu ustalanego z rozporządzania papierami wartościowymi w ramach „krótkiej sprzedaży”, w którym momencie należy rozpoznać przychód z czynności rozporządzania rzeczą przechowywaną w depozycie nieprawidłowym. Podobnie brak w PdopU regulacji dotyczących ustalenia kosztów uzyskania tego przychodu.

Nie jest zasadnym postulowanie stworzenia odrębnej regulacji przeznaczonej wyłącznie dla rozporządzania rzeczą przechowywanej w depozycie nieprawidłowym, bowiem może to przyczynić się do niepotrzebnego wzrostu kazuistyki w przepisach PdopU.

Prawidłowym, jak się wydaje, na kanwie stanowiska organu podatkowego oraz sądów administracyjnych sposobem ustalenia przychodu z rozporządzania rzeczą przechowywaną $w$ depozycie nieprawidłowym winno być rozpoznanie na podstawie art. 12 ust. 3 PdopU w powiązaniu z art. 12 ust. 1 pkt 1 przychodu ze zbycia rzeczy z depozytu nieprawidłowego i rozpoznanie jego w momencie wygaśnięcia stosunku prawnego depozytu nieprawidłowego. Takie ustalenie

22 Wyrok NSA z dnia 14 stycznia 2010 r., II FSK 1286/08, CBOSA. 
przychodu jest istotne ze względu na moment ustalenia kosztu uzyskania przychodu, który, jak wynika a contrario z przedstawionej powyżej interpretacji indywidualnej oraz orzeczenia sądu administracyjnego, powinien być rozpoznawany jako wartość pieniężna, jaką depozytariusz przeznaczył na nabycie takiej samej ilości rzeczy tego samego gatunku i jakości w takiej samej formie, jaką przyjął w depozyt nieprawidłowy.

Rozwiązanie to stoi w sprzeczności z ujęciem rozporządzania rzeczą przechowywaną $\mathrm{w}$ depozycie nieprawidłowym $\mathrm{w}$ prawie bilansowym, bowiem na kanwie ustawy z dnia 29 września 1994 r. o rachunkowości, z każdej transakcji sprzedaży rzeczy przechowywanej w depozycie nieprawidłowym, w ujęciu prawa bilansowego, rozpoznawany będzie przychód oraz koszt jego uzyskania. Jednak odmienne rozpoznanie kwestii ustalania przychodu oraz kosztów jego uzyskania w ujęciu prawa podatkowego oraz prawa bilansowego jest zgodne ze wskazaniami zawartymi w przywoływanej powyżej interpretacji indywidualnej z dnia 18 grudnia 2014 r., gdzie organ podatkowy słusznie podkreślił, że cel prawa podatkowego i cel prawa bilansowego jest odmienny, w związku z czym rozbieżności co do momentu ujęcia danej wartości jako przychód bądź kosztu jego uzyskania jest prawidłowa.

Reasumując, przychodem z czynności rozporządzania rzeczą przechowywaną $\mathrm{w}$ depozycie nieprawidłowym jest wartość pieniężna uzyskana z transakcji zbycia tej rzeczy. Natomiast kosztem uzyskania tego przychodu jest wartość rzeczy takiej samej ilości, tego samego gatunku i jakości w takiej samej formie, jaka została złożona do depozytu nieprawidłowego, którą przechowawca musi nabyć w celu zwrotu tej rzeczy stronie umowy depozytu nieprawidłowego.

\section{Bibliografia:}

Adamczuk J., Szewc W., Ziółkowska K., Ujęcie przychodów według regulacji prawa bilansowego i podatkowego w Polsce, „Zeszyty Teoretyczne Rachunkowości” 2010, t. 54, s. 5-17.

Borszowski P., Działalność gospodarcza w konstrukcji prawnej podatku, Wolters Kluwer, Warszawa 2010. 
Czachórski W., Zobowiq̨zania. Zarys wykładu, Wydanie jedenaste, Lexis Nexis, Warszawa 2009.

Bień W., Rynek papierów wartościowych, wyd. VII, Difin, Warszawa 2007.

Gomułowicz A., Prawna formuła kosztu podatkowego, Wolters Kluwer, Warszawa 2016.

Golat R., Umowa depozytu nieprawidłowego - implikacje w podatku dochodowym, Komentarz praktyczny ABC, Wolters Kluwer, LEX nr 469833737.

Kopaczyńska-Pieczniak K., Komentarz do art. 845 Kodeksu Cywilnego, [w:] A. Kidyba (red.), Kodeks cywilny. Komentarz. Tom III. Zobowiqzania część szczególna, wyd. II, Wolters Kluwer SA, LEX nr 46294. 